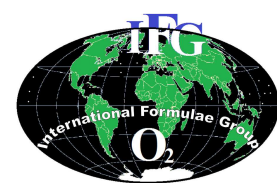

Available online at http://ajol.info/index.php/ijbes

Int. J. Biol. Chem. Sci. 8(2): 494-507, April 2014

International Joumnal

ISSN 1997-342X (Online), ISSN 1991-8631 (Print)

Original Paper

http://indexmedicus.afro.who.int

\title{
Acute and sub-lethal toxicological evaluation of flavonoid fraction of Monodora myristica Geartn Dunnel seeds
}

\author{
Kemi FEYISAYO AKINWUNMI ${ }^{1 *}$, Oluboade OLUOKUN OYEDAPO ${ }^{1}$ and \\ Josiah BABATUNDE OLASODE ${ }^{2}$
}

${ }^{I}$ Department of Biochemistry, Obafemi Awolowo University Ile-Ife, Nigeria.

${ }^{2}$ Department of Morbid Anatomy Obafemi Awolowo University Teaching Hospital Ile-Ife, Nigeria

"Corresponding author: E-mail; kfarinde@yahoo.com ; kakinwunmi@oauife.edu.ng ;

Tel : +2348053444973

\begin{abstract}
This study investigated acute toxicity of flavonoid fraction of Monodora myristica in mice and sub lethal toxicity in rabbits. Powdered seed of M. myristica $(312 \mathrm{~g})$ was extracted with $2.5 \mathrm{~L}$ of $70 \%(\mathrm{v} / \mathrm{v})$ ethanol for $24 \mathrm{~h}$ followed by concentration under reduced pressure at $40{ }^{\circ} \mathrm{C}$ to obtain a brown residue termed ethanolic extract (EE). The EE was subjected to solvent-solvent partitioning with ethyl acetate to obtain the flavonoid fraction (FF). The acute toxicity test involved oral administration of graded doses of FF of M. myristica to six groups of mice. Biochemical changes as a result of sub lethal exposure of FF to rabbits were investigated at $500 \mathrm{mg} / \mathrm{kg}$ bwt and $1000 \mathrm{mg} / \mathrm{kg}$ bwt for 28 days. The effects of the extract of M. myristica on total protein, albumin, bilirubin, creatinine, urea, as well as the activities on specific marker enzymes (L-alanine and Laspartate aminotransferases, alkaline and acid phosphatases and gamma glutamyltransferase) were evaluated in the plasma and liver homogenates of rabbits. The histopathological evaluation of the liver, brain, heart, lungs and kidney of rabbits were carried out. FF of $M$. myristica was observed to be non toxic in mice with $\mathrm{LD}_{50}$ greater than $5000 \mathrm{mg} / \mathrm{kg}$ bwt. There were no significant differences $(\mathrm{p}>0.05)$ in the total protein, albumin, bilirubin, creatinine, uric acid, urea levels in the liver and plasma of treated animals. Moreover, some activities of specific marker enzymes such as L-alanine and L-aspartate aminotransferases, acid and alkaline phosphatases and gamma glutamytransferase were not adversely affected. Histopathological findings showed no significant differences between control and the treated groups and revealed that the brain, lungs, heart, liver and kidney tissues of rabbit were not adversely affected.
\end{abstract}

(c) 2014 International Formulae Group. All rights reserved.

Keywords: Ethanolic extracts (EE), flavonoid fraction (FF), toxicity, Monodora myristica (MM).

\section{INTRODUCTION}

Monodora myristica belongs to the custard apple family of flowering plants Annonaecea. The generic name was derived from the Greek word meaning "single gift" (Ekeanyanwu et al., 2010). It grows well in the evergreen forest of West Africa and most prevalent in the Southern part of Nigeria (Adegoke and Akinsanya, 1970; Keay, 1989; Omobuwajo et al., 2003). Its native names include: Ehuru or Ehiri (Igbo), Ariwo or Lakosin (Yoruba), Ehinawosin (Ikale), 
Uyengben (Edo), Jamaica nutmeg, African nutmeg, Calabash nutmeg, Airama (Keay, 1989).

M. myristica seed is oblongoid in shape and pale brown in colour with a thin seed coat and hard kernel (Nesaretnam and Muhammad, 1999). The seeds are aromatic and are employed after grinding to a powder as condiments in food providing a flavour resembling that of nutmeg and as an aromatic and stimulating addition to medicines and to snuff (Burkill, 1985; Okafor, 1987; Ekeanyawu et al., 2010). Moreover, the seeds are used in African cooking especially with shrimp and in pepper soup as stimulant to relieve constipation and control passive uterine hemorrhage in women immediately after child birth (Okafor, 1987; Udeala, 2000; Iwu, 2002).

Phytochemical studies have shown that the seeds are rich in alkaloids, glycosides, flavonoids, tannins, saponins and steroids (Uheghu et al., 2011; Ekeanyanwu et al., 2012). They contain about 5-9\% of a colourless essential oil with a pleasant taste and smell consisting largely of terpenes (Igwe et al., 2005; Owolabi el al., 2008). Also, the seeds contain about $35-36 \%$ of a reddishbrown fixed oil which is mainly linoleic acid $(46.9 \%)$, oleic acid $(35 \%)$ and arachidic acid $(9.52 \%)$ and are rich in potassium, magnesium, phosphorus, calcium and iron (Ajayi et al., 2004; Burubai et al., 2009; Uheghu et al., 2011).

It has been reported that ethanolic extract of $M$. myristica seed possesses antimicrobial activity against Klebsiella and Bacillus species (Aboaba et al., 2011) and possess broad spectrum antibacterial activities against selected gramme positive and negative bacteria (Ogu et al., 2011). Aqueous extracts of $M$. myristca have equally been reported to possess anti-amylase activities which may be potentially useful in the treatment and management of diabetes mellitus and obesity (McCue and Shetty, 2004; Oben et al., 2010) due to the presence of phenolic compounds (Rhon et al., 2002; Arts et al., 2002). Despite the profound therapeutic advantages possessed by this spices, little or no information is available in the literature about the safety or toxicity of the spice. This study however provides information on toxicological effects of these spices in order to provide basis for its continual consumption.

\section{MATERIALS AND METHODS \\ Collection of plant material}

Dried seeds of $M$. myristica were purchased from Sabo Market in Ile-Ife, Nigeria. The seeds were identified and authenticated at IFE Herbarium, Obafemi Awolowo University, Ile-Ife, Nigeria, with voucher specimen reference number 4734 . The seeds were decocted to release the kernels which were later ground to fine powder with electronic blending machine.

\section{Animals}

Twenty four Swiss albino mice of either sex weighing between 20-24 g were procured from the Faculty of Pharmacy, Obafemi Awolowo University, Ile-Ife, Nigeria. Healthy rabbits (15) were also obtained at the age of four to six weeks old from Zoological Garden, Obafemi Awolowo University, Ile-Ife. The animals were kept in the laboratory cages at $25{ }^{\circ} \mathrm{C} \pm 2{ }^{\circ} \mathrm{C}$. The animals were acclimatized to the laboratory conditions for two weeks before commencement of investigation. They were fed with Standard chow (Ladokun feeds, Ibadan) and water ad libitum throughout the period of experiment.

\section{Reagents and chemicals}

All reagents used were of the analytical grade and were obtained from different 
sources such as Sigma-Aldrich Company and British Drug House (BDH) Chemical Limited England. Diagnostic kits for the assays of alanine aminotransferase, aspartate aminotransferase, L-gammaglutamyltransferase, bilirubin, urea were obtained from Randox Laboratory Ltd. Antrium, U.K. All solutions, buffers and reagents were prepared with glass distilled water and stored in the refrigerator.

\section{Methodology \\ Extraction}

The powdered seed was defatted with petroleum ether and then extracted with aqueous ethanol $(70 \% \mathrm{v} / \mathrm{v})$ according to the procedure earlier described by Oyedapo et al. (2004). Typically, $400 \mathrm{~g}$ of defatted seeds of M. myristica was suspended in aqueous ethanol $(70 \% \mathrm{v} / \mathrm{v}, 1 \mathrm{~L})$. The suspension was stirred occasionally and kept at room temperature for $24 \mathrm{~h}$. The supernatant was collected by filtration through two layers of cheese cloth followed by filtration with filter paper Whatman number 2. The residue was washed with $70 \%(\mathrm{v} / \mathrm{v})$ ethanol until the supernatant was clear. The filtrates were combined and concentrated under reduced pressure on rotatory evaporator at $40{ }^{\circ} \mathrm{C}$ to afford a brown residue termed ethanolic extract (EE) of M. myristica seed.

Partitioning of ethanolic extract of Monodora myristica

The ethanolic extract was partitioned by solvent-solvent extraction according to a procedure that was based on those reported by Aderogba et al. (2007). Typically, concentrated ethanolic extract $(20 \mathrm{~g})$ was taken up in hot distilled water $(0.2 \mathrm{~L})$. This was successively extracted with $1 \mathrm{~L}$ of $\mathrm{n}$ hexane, dichloromethane, ethyl acetate and nbutanol in a separating funnel $(1 \mathrm{~L})$ to afford four fractions namely n-HexF, DCMF, EAF and $\mathrm{nBF}$ respectively. Each of the four fractions was concentrated to dryness on a rotatory evaporator at $40{ }^{\circ} \mathrm{C}$. Chemical reaction and thin layer chromatography revealed that EAF contained the bulk of the seed flavonoid; as such was employed as flavonoid fraction (FF).

\section{Acute toxicity test}

The acute toxicity $\left(\mathrm{LD}_{50}\right)$ was estimated in mice as described by Lorke et al. (1983) with slight modifications. The test was carried out in two phases. In the first phase, 12 mice were randomly divided into 4 groups $(3$ mice per group) and FF of $M$. myristica was administered at 10, 100 and $1000 \mathrm{mg} / \mathrm{kg}$ body weight orally to the three groups while the other group served as control. The second phase was performed after $24 \mathrm{hrs}$ based on the observation and the number of survivors in the first phase. Twelve mice (12) were divided into 4 groups ( 3 mice per group) and 1600 , 2900 and $5000 \mathrm{mg} / \mathrm{kg}$ bwt of FF of $M$. myristica was administered orally. The mice were observed for toxic symptoms at $1 / 2,1,2$, 6 and $24 \mathrm{~h}$ after administration. The $\mathrm{LD}_{50}$ value was calculated from the plot of percentage mortality versus log of concentration.

\section{Sub-lethal toxicity test}

Fifteen (15) rabbits were randomly divided into three groups of five rabbit each. Group 1 served as the control given only normal saline while the remaining two groups received 500 and $1000 \mathrm{mg} / \mathrm{kg}$ bwt of FF orally every other day for a period of 28 days and daily visual observations were made.

\section{Sacrificing and collection of tissues of experimental animals}

The experimental animals were fasted overnight before they were anesthetized with chloroform on the $29^{\text {th }}$ day. The animals were cut open ventrally; blood was collected by direct cardiac puncture into clean sterilized centrifuge tubes with 21 guage syringes that contained heparin. Tissues (liver, kidney, 
heart, lungs and brain) were collected aseptically, cleaned and drained of blood, folded in aluminium foil and kept in the Royal Deep Freezer until further analyzed. Certain portions of the tissues were preserved in $10 \%$ buffered formalin for histological examination.

\section{Preparation of blood plasma}

Blood samples $(10 \mathrm{ml})$ were centrifuged at 3,000 rpm on Galemkamp Junior Table Centrifuge for $10 \mathrm{~min}$. The plasma was collected, transferred into sterile vials and kept frozen for biochemical analyses.

\section{Preparation of liver post mitochondrial fractions}

Liver samples $(1.0 \mathrm{~g})$ were weighed separately from each group and homogenized with $10 \mathrm{ml}$ of ice - cold $10 \mathrm{mM}$ Tris $-\mathrm{HCl}$ buffer, $\mathrm{pH} 7.4$ in a mortar with pestle and washed sand was added to act as abrasive to aid homogenization. The homogenates were centrifuged at $3000 \mathrm{rpm}$ for $10 \mathrm{~min}$. The supernatants were collected into clean dried bottles with appropriate labels and kept in deep freezer for biochemical analyses.

\section{Histopathology}

In order to evaluate the effect of FF on the gross morphology of the liver, the kidney, the heart, the lung and brain tissues of the rabbits, histology examination was carried out. Tissue biopsies from liver, kidney, brain lungs and heart were fixed in Bouin fluid (Picric acid + formalin acetic acid). The tissue biopsies were processed with automated tissue processor (Citadel, 2000) and embedded in paraffin. Sections $6 \mu \mathrm{m}$ thickness were cut with rotary microtome and stained with haematoxylin and eosin (HE) for morphology assessment. Histological sections were examined using Leica light microscope and were photographed.

\section{Biochemical assay}

Biochemical assays were carried out on the plasma and liver homogenate as follows: estimation of total protein concentrations by quantitative assay method of small amount of protein in biological membrane as described by Schacterk and Pollack (1973) with bovine albumin as standard. Albumin concentration was estimated by modified procedure of Pinnell and Northan (1978) using bromocresol green (BCG).

The aminotransferases (L-alanine and L- aspartate) were assayed according to the colorimetric method of Reitman and Frankel (1957) using Randox Diagnostic Kit, (ALT, AST-Test, Randox laboratory Ltd.UK). The assay mixture consisted of blood plasma (100 $\mu 1)$ and Alanine aminotransferase (ALT) substrate $(500 \mu \mathrm{l})$ followed by incubation at $37{ }^{\circ} \mathrm{C}$ for $30 \mathrm{~min}$. The colour reagent $(500 \mu \mathrm{l})$ was added and the mixture was mixed properly and allowed to stand at room temperature for another $20 \mathrm{~min}$. After which 5 $\mathrm{ml}$ of $0.4 \mathrm{M} \mathrm{NaOH}$ solution was added to terminate the reaction. The absorbance was read at $546 \mathrm{~nm}$ against the blank after $5 \mathrm{~min}$. The activity of the enzyme was extrapolated from the standard calibration curve obtained from an absorbance-enzyme activity table of values provided by the manufacturer in the kit. Enzyme activity was expressed in IU/L protein. One unit of alanine aminotransferase activity was defined as the amount of protein that liberated one $\mu$ mole of pyruvate per $\mathrm{ml} /$ min under experimental condition. Aspartate aminotransferase (AST) was assayed as described above using AST substrate. One unit of AST activity was defined as the amount of protein that liberated one mole of oxaloacetate $/ \mathrm{ml} / \mathrm{min}$ under experimental condition.

Phosphatases (Alkaline and Acid) were assayed according to the procedure of Saini and Van-Etten (1979) as described by 
Oyedapo (1996). The assay mixture consisted of $25 \mu \mathrm{l}$ of plasma, $1000 \mu \mathrm{l}$ of $10 \mathrm{mM}$ nitrophenyl phosphate in $10 \mathrm{mM}$ acetate buffer, pH 4.5 containing $5 \mathrm{mM} \mathrm{NaCl}$ as substrate. This was incubated at $37{ }^{\circ} \mathrm{C}$ for 15 min. after which $2.0 \mathrm{ml}$ of $0.02 \mathrm{M} \mathrm{NaOH}$ was added to terminate the reaction. The absorbance of the resulting p-nitrophenonate ion was read at $410 \mathrm{~nm}$ against the reagent blank. The activity was expressed as $\mu$ mole $\mathrm{p}$ nitrophenol liberated/min. Alkaline phosphatase activity was assayed as described above except that the substrate $(10 \mathrm{mM}$ nitrophenylphosphate) was prepared in 10 $\mathrm{mM}$ Tris- $\mathrm{HCl}$ buffer, $\mathrm{pH} 9.2$ containing $5 \mathrm{mM}$ $\mathrm{MgCl}_{2} \cdot 6 \mathrm{H}_{2} \mathrm{O}$. The activity was also expressed as $\mu$ mole p-nitro phenol liberated $/ \mathrm{min}$.

Total and conjugated bilirubin was estimated as described by Jendrassik and Groff (1938) using Randox diagnostic kit.

The plasma L- gamma glutamyltransferase activity was determined using Randox Diagnostic and the absorbance of 5-amino-2-nitrobenzoate was measured spectrophotometrically at $405 \mathrm{~nm}$.

The plasma creatinine was estimated using Jaffe's-alkaline picrate method as described by Chawla (1999). The plasma protein was precipitated by the addition of 2 $\mathrm{ml}$ of $10 \%(\mathrm{w} / \mathrm{v})$ sodium tungstate and $2 \mathrm{ml}$ of $0.67 \mathrm{M}$ sulphuric acid to $2 \mathrm{ml}$ of plasma and the supernatant was used for creatinine determination. The test consisted of $3 \mathrm{ml}$ supernatant, $2.5 \mathrm{M} \mathrm{NaOH}(1 \mathrm{ml})$ and $0.04 \mathrm{M}$ picric acid $(1 \mathrm{ml})$. The reaction mixtures were mixed thoroughly and incubated for $10 \mathrm{~min}$ after which the absorbance was read at 520 nm against the blank.

Concentration of urea in the plasma was estimated by the colorimetric method of Berthelot (1976) using commercially available kit by Randox Laboratories Ltd, Antrim, UK. Uric acid concentration in the plasma was estimated using Caraways method as described by Chawla (1999).

\section{Statistical analysis}

Data for biochemical assays were expressed as mean \pm SEM. Statistical analysis was performed by one way ANOVA followed by Turkey-Kramer multiple comparison test to ascertain differences between treatment groups. Analysis was performed using GraphPad Instant 3 (version1.1, 2007).

\section{RESULTS}

Yield of ethanolic extract and fractions

The exhaustive extraction of $312.14 \mathrm{~g}$ of $M$. myristica seeds yielded $41.03 \mathrm{~g}$ of EE, this represented $13.14 \%$ of the starting material.

The partitioning of ethanolic extract of M. myristica with n-hexane (n-Hex), dichloromethane (DCM), ethyl acetate (EtoAC) and butanol $(\mathrm{BuOH})$ yielded four fractions. n-HF, DCMF, EAF, and $\mathrm{nBF}$ numbered 1, 2, 3 and 4 respectively. Ethyl acetate fraction (EAF) contained the highest amount of flavonoids (Table 1), hence it was termed the flavonoid fraction.

\section{Acute toxicity of flavonoids of $\boldsymbol{M}$. myristica}

At the dose levels tested, there were no toxic symptoms observed in the treated mice. No mortality was observed in all the groups of mice that were given FF of $M$. myristica orally after $72 \mathrm{~h}$ (Table 2). Therefore the $\mathrm{LD}_{50}$ (which was a statistically derived dose that when administered in an acute toxicity test was expected to cause death in $50 \%$ of the treated animals in a given period) value of $M$. myristica was estimated to be above 5000 $\mathrm{mg} / \mathrm{kg}$ bwt. This implied that FF of $M$. myristica was acutely non toxic. 


\section{Sub lethal toxicity}

Ten rabbits (10) were exposed to FF of M. myristica at $500 \mathrm{mg} / \mathrm{kg}$ bwt and 1000 $\mathrm{mg} / \mathrm{kg}$ bwt concentrations every other day for a period of 28 days. Plasma and liver homogenates were prepared. The result of the biochemical parameters investigated in the plasma and liver homogenate is presented in Tables 3 and 4 respectively.

\section{Histophatology}

Histopathological examination of the brain, kidney, heart, lung and the liver were performed. The brain of the rabbits in the control and the two treated groups showed no histological alteration Figure $1 \mathrm{~A}\left(\mathrm{M}_{0}, \mathrm{M}_{1}\right.$ and $\mathrm{M}_{2}$ ). The glomeruli and the tubules of the kidney of the control and treated rabbits Figure $1 \mathrm{~B}\left(\mathrm{M}_{0}, \mathrm{M}_{1}\right.$ and $\left.\mathrm{M}_{2}\right)$ were normal. A detailed scrutiny of histoarchitecture of the heart of the control and treated groups did not reveal any observable cellular damage Figure $1 \mathrm{C}\left(\mathrm{M}_{0}, \mathrm{M}_{1}\right.$ and $\left.\mathrm{M}_{2}\right)$. The liver tissues of the control and the treated groups revealed normal architecture and hepatocytes distribution with granulated cytoplasm Figure $1 \mathrm{D}\left(\mathrm{M}_{0}, \mathrm{M}_{1}\right.$ and $\mathbf{M}_{2}$ ). The lung tissues of the rabbits in the control and the two treated groups showed normal cellular morphology and tissue integrity Figure $1 \mathrm{E}\left(\mathrm{M}_{0}, \mathrm{M}_{1}\right.$ and $\left.\mathrm{M}_{2}\right)$.

Table 1: Partitioning of ethanolic extracts of Monodora myristica.

\begin{tabular}{lccc}
\hline Fraction number & Fraction name & $\begin{array}{c}\text { Flavonoid } \\
\text { concentration }(\mathbf{m g} / \mathbf{g})\end{array}$ & \% Flavonoid content \\
\hline $\mathbf{1}$ & Hexane & - & - \\
$\mathbf{2}$ & DCM & 0.18 & 4.31 \\
$\mathbf{3}$ & EtOAc & 3.40 & 81.34 \\
$\mathbf{4}$ & $\mathrm{BuOH}$ & 0.60 & 14.35 \\
\hline
\end{tabular}

Table 2: Acute toxicity test of flavonoid fraction of Monodora myristica.

\begin{tabular}{lcc}
\hline Phase of toxicity test & Dose $(\mathbf{m g} / \mathbf{k g}$ body weight) & Number of deaths recorded \\
\hline \multirow{3}{*}{ Phase I } & 10 & $0 / 4$ \\
& 100 & $0 / 4$ \\
& 1000 & $0 / 4$ \\
\multirow{3}{*}{ Phase II } & 1600 & $0 / 4$ \\
& 2900 & $0 / 4$ \\
\hline
\end{tabular}


K. FEYISAYO AKINWUNMI et al. / Int. J. Biol. Chem. Sci. 8(2): 494-507, 2014

Table 3: Effects of flavonoid fraction of Monodora myristica treatments on biochemical blood plasma parameters of rabbits.

\begin{tabular}{|c|c|c|c|}
\hline Biochemical Parameters & Group I ( Control) & Group II ( 500 mg/kg bwt) & Group III ( 1000 mg/kg bwt) \\
\hline Total protein $(\mathrm{g} / \mathrm{dL})$ & $5.72 \pm 0.91$ & $5.75 \pm 0.32$ & $5.56 \pm 1.20$ \\
\hline $\operatorname{Albumin}(\mathrm{g} / \mathrm{dL})$ & $3.46 \pm 0.02$ & $3.27 \pm 0.03$ & $3.27 \pm 0.08$ \\
\hline Total bilirubin $(\mathrm{mg} / \mathrm{L})$ & $1.36 \pm 0.08$ & $1.36 \pm 0.09$ & $1.40 \pm 0.11$ \\
\hline $\operatorname{Direct}$ bilirubin(mg/L) & $0.52 \pm 0.02$ & $0.47 \pm 0.01$ & $0.52 \pm 0.04$ \\
\hline Alkaline phosphatase ( $\mu$ mol p-nitro phenyl/min/) & $89.23 \pm 3.95$ & $84.821 \pm 7.79$ & $88.65 \pm 10.03$ \\
\hline Acid phosphatase ( $\mu \mathrm{mol}$ p-nitro phenyl/min/) & $72.33 \pm 3.30$ & $71.44 \pm 3.31$ & $72.24 \pm 4.16$ \\
\hline ALT (IU/L) & $32.00 \pm 1.05$ & $36.80 \pm 2.09$ & $35.80 \pm 2.75$ \\
\hline AST (IU/L) & $115.50 \pm 2.18$ & $116.00 \pm 2.35$ & $112.50 \pm 0.63$ \\
\hline Creatinine $(\mathrm{mg} / \mathrm{dl})$ & $1.00 \pm 0.02$ & $1.03 \pm 0.08$ & $1.06 \pm 0.07$ \\
\hline Urea (mmol/L) & $1.20 \pm 0.13$ & $1.91 \pm 0.21$ & $1.91 \pm 0.11$ \\
\hline Uric acid (mmol/L) & $0.32 \pm 0.02$ & $0.32 \pm 0.04$ & $0.31 \pm 0.02$ \\
\hline
\end{tabular}

Each value represented mean \pm SEM $n=5$. Values were taken to be statistically significant at $\mathrm{P}<0.05$ by using analysis of variance (ANOVA). 
Table 4: Effects of flavonoid fraction of Monodora myristica treatment on rabbit liver homogenate parameters.

\begin{tabular}{|c|c|c|c|}
\hline Biochemical Parameters & Group I (Control) & Group II ( 500 mg/kg bwt) & Group III ( 1000 mg/kg bwt) \\
\hline Total protein $(\mathrm{mg} / \mathrm{ml})$ & $12.00 \pm 0.05$ & $11.89 \pm 0.04$ & $11.94 \pm 0.03$ \\
\hline Albumin $(\mathrm{g} / \mathrm{dl})$ & $3.01 \pm 0.09$ & $2.85 \pm 0.09$ & $3.05 \pm 0.03$ \\
\hline Total bilirubin (mg/L) & $1.94 \pm 0.11$ & $1.82 \pm 0.06$ & $.86 \pm 0.22$ \\
\hline Direct bilirubin $(\mathrm{mg} / \mathrm{L})$ & $0.89 \pm 0.04$ & $0.84 \pm 0.04$ & $0.83 \pm 0.03$ \\
\hline $\begin{array}{l}\text { Alkaline phosphatase } \\
(\mu \mathrm{mol} \text { p-nitro phenyl/min/mg protein) }\end{array}$ & $277.12 \pm 8.65$ & $273.42 \pm 4.90$ & $275.98 \pm 6.10$ \\
\hline $\begin{array}{l}\text { Acid phosphatase } \\
\text { ( } \mu \text { mol p-nitro phenyl } / \mathrm{min} / \mathrm{mg} \text { protein) }\end{array}$ & $536.34 \pm 13.49$ & $482.61 \pm 20.14$ & $512.03 \pm 16.47$ \\
\hline ALT (IU/L) & $136.40 \pm 2.66$ & $131.20 \pm 2.58$ & $133.20 \pm 1.66$ \\
\hline AST (IU/L) & $115.50 \pm 2.18$ & $116.00 \pm 2.44$ & $112.50 \pm 0.63$ \\
\hline
\end{tabular}


$\mathrm{M}_{0}$

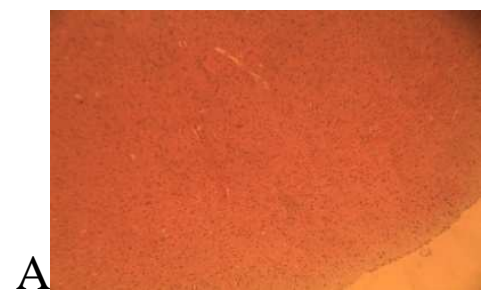

$\mathrm{B}$
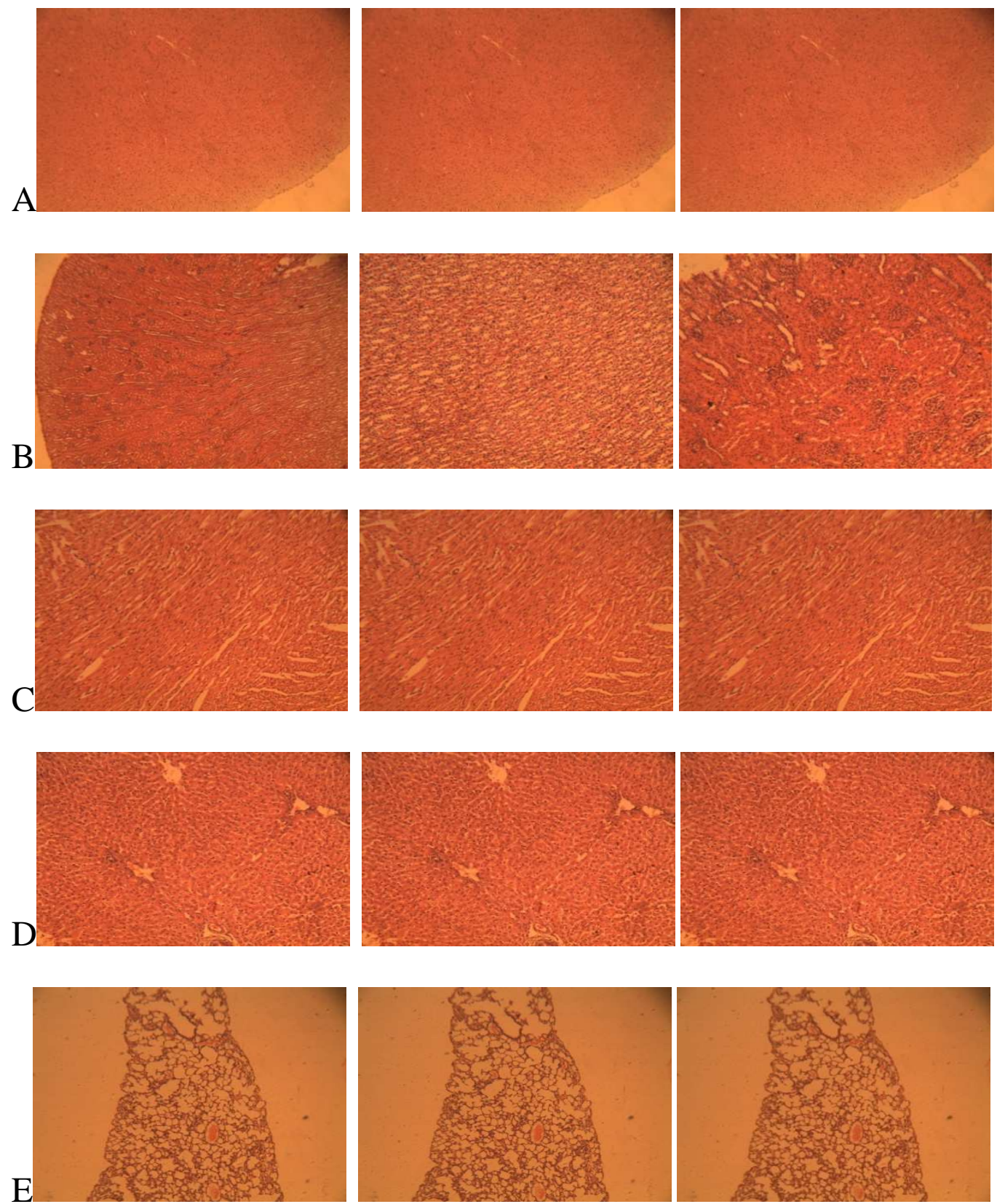

Figure 1: Photomicrographs (x16) of the sections of the brain (A), kidney (B), heart (C), liver (D) and lungs (E) of control $\left(\mathrm{M}_{0}\right)$ and treated groups $\left(\mathrm{M}_{1}\right.$ and $\left.\mathrm{M}_{2}\right)$ administered FF of $M$. myristica orally at $500 \mathrm{mg} / \mathrm{kg}$ bwt and $1000 \mathrm{mg} / \mathrm{kg}$ bwt respectively for 28 days showing no histoarchitectural change in treated groups as compared to control. 


\section{DISCUSSION}

Monodora myristica seed is an African spice used in the preparation of "Pepper-soup", a traditional African sauce used for the healthy, the sick or convalescing and for general health improvement. It is a popular condiment used as a spicing agent in both African and continental cuisines in Nigeria. Despite the profound therapeutic advantages possessed by this spice, little or no information is available in the literature about the safety or toxicity of the spice.

Toxicity testing in animals is commonly used to assess potential health risk in humans caused by intrinsic adverse effects of chemical compounds or plant extracts (Oyedemi et al., 2010). These adverse effects may manifest in the form of significant alterations in the levels of biomolecules such as enzymes and metabolic products, normal functioning and histomorphology of the organs.

Acute toxicity testing measures the adverse effects that occur within a short term of administration of single dose of a chemical. It provides information on the health hazards that is likely to arise from short-term exposure and is usually an initial step in the evaluation of toxic characteristic for both health and environmental effects. Acute testing can be used to identify doses associated with target organ toxicity and lethality that may be referable to humans. It was used to standardize biological product and can serve to establish dosing level of repeated dose studies (Amy et al., 2002). Evaluation of acute toxicity of FF of M. myristica in mice resulted in no lethality of the mice and no toxic symptoms were observed at $5000 \mathrm{mg} / \mathrm{kg}$ bwt. This implied that FF of $M$. myristica is acutely non toxic (OECD 401).

The prolong effects (due to repeated exposure of the spices) on some biochemical parameters were investigated in the plasma and the liver homogenate of rabbit. Liver is the largest organ in the body and it performs numerous metabolic, secretory, excretory, storage and detoxifying functions. It is the site for the synthesis of protein, albumin, bilirubin and marker enzymes such as aminotransferases (L-alanine and L- aspartate) as well as phosphatases (alkaline and acid). Several biochemical tests are available to assess the functional efficacy of this organ. In this study, the following biochemical analyses were carried out to assess the functional efficacy of the rabbit liver following administration of different concentrations (500 mg/kg bwt and $1000 \mathrm{mg} / \mathrm{kg}$ bwt) of FF of $M$. myristica: total protein, albumin level, aminotransferases (ALT and AST), phosphatases (acid and alkaline) and bilirubin levels.

Proteins are synthesized in the liver which is the architecture of the cell and during chronic stress; they serve as source of energy (Mommensen and Walsh, 1992). Serum or plasma protein represents a complex mixture containing a number of components which differs in properties and function. The major plasma /serum proteins include albumin, globulin, conjugated proteins such as glycoprotein and mucoprotein, protein polysaccharide compounds, lipoproteins and fibrinogen in the plasma (Chawla, 1999).

Albumin contributes to the amino acid pool and plasma colloid osmotic pressure counteracting the effects of capillary blood pressure which tends to force water into tissue spaces. Albumin also helps in transport of a wide range of naturally occurring substances such as bilirubin, fatty acids, urate, calcium, magnesium and drugs. In this study, the albumin level in both the plasma and the liver varies slightly but the difference is not significant $(p>0.05)$ in both the liver and the plasma when compared with the control. This implied that albumin metabolism by the liver was not affected by the administration of FF of M. myristica.

Aminotransferases catalyses the transfer of amino group from an- amino acid to an $\alpha$-oxo acid a process that is essential in metabolism of amino acid. There are two types of aminotransferases that are of diagnostic significant. Both AST and ALT are excellent markers of liver damage caused by exposure to toxic substances (James and Eagles, 2010). ALT is found in high concentration in the liver. The heart, liver, 
skeletal muscle and kidney are rich in AST as such increase in plasma ALT concentration was an indication of liver damage (Brautbar and Williams, 2002). Since AST was found in other tissues other than the liver, any increase in plasma AST might also be due to necrosis and inflammation of the heart, liver, kidney and muscle tissues. Observations from the findings of this study revealed that there was no significant difference ( $p>0.05$ ) in ALT and AST concentrations between the control and the treated groups. Thus, no significant increases observed in ALT and AST activities strongly suggest that the sub lethal administration of FF did not alter the hepatocytes and consequently the metabolism in the rabbits.

Phosphatases (acid ad alkaline) catalyse the splitting of phosphoric acid from monophosphoric esters such as glycophosphates and phenyl phosphate. Alkaline phosphatase is a membrane bound enzymes with maximum activity at about $\mathrm{pH}$ 10. It is the most active and the one longest recognized. It is present in most tissues such as bile canaliculi in the liver, small intestinal epithelium, osteoblast in the bone, proximal tubules in the kidney. The response of the liver to any form of biliary obstruction is to synthesis more alkaline phosphatase in the hepatocytes (Yadav and Singh, 2003). It is often used to assess the integrity of plasma membranes and hepatic functions (Akanji et al., 1993). Acid phosphatases are hydrolytic lysosomal enzymes that are released by lysosomes for the hydrolysis of foreign materials. It is present in the prostate gland and function optimally at $\mathrm{pH}$ 5.4. Acid phosphatase is an inducible enzyme whose activity in animal tissues goes up when there is toxic impact to counteract or as a result of cell damage (Jaroli and Sharma, 2005). In this study, there was no significant difference ( $p>0.05)$ in both the acid phosphatase as well as in alkaline phosphates between the treated and the control groups. This implied that FF of $M$. myristica had little or no effect on the acid and alkaline phosphatase concentrations in the liver and the prostate gland.
Gamma glutamyl transferase is a membrane bound glycoprotein which catalyses the transfer of the gamma glutaryl moiety of glutathione to various peptide acceptors (Gopinath et al., 2010). It is present in the plasma membrane of renal tubular cells and endoplasmic reticulum of hepatocytes and bile duct cells. GGT also participates in peptide nitrogen storage and in protein biosynthesis. GGT present in serum/plasma originates primarily from hepato-biliary system (Limdi and Hyde, 2003) and its increase in plasma/serum is considered a significant enzymatic parameter in alcohol liver disease and hepatobiliary diseases (Rossalki 1975). In this study, there was no significant difference in GGT concentration between the control and the treated groups.

Bilirubin is formed from haemoglobin and other haem groups in the reticuloendothelia system (spleen, bone marrow, and Kupffer cells of the liver). Total (unconjugated) bilirubin is not water soluble, as such; albumin binding aids its transportation across the watery plasma. Direct (conjugated) bilirubin is water soluble and when present in the blood can be filtered through glomerulus appearing in the urine. Secretion of conjugated bilirubin in bile across the biliary canalicular membrane is a rate limiting process and is sensitive to liver damage. Evident from this study, there was no significant difference in the bilirubin (total and conjugated) concentrations ( $p>0.05$ ) between the control and the treated rabbit groups. This implied that FF of M. myristica had little or no effects on the excretion of bilirubin.

Kidneys are the major excretory organs and renal function tests are devised to detect possible renal damage. In order to evaluate the effect of extract of FF of $M$. myristica on the functional efficiency of the kidney, urea, creatinine and uric acid levels in the plasma of the control and treated rabbits were estimated.

Urea is the end product of protein catabolism which is excreted by the kidney. Elevation in urea concentration in the plasma is an indication of renal impairment or kidney 
failure (Davis and Bredt, 1994). Evident from this study, there was no significant difference ( $>0.05)$ in urea concentration between the control and treated groups.

Creatinine is the waste product formed in the muscle by creatine metabolism and it is excreted by the kidney. Increased plasma/serum creatinine level is seen in renal failure or renal disease. In this study, there was a slight increase in plasma creatinine level of the treated animals but the increase was not significant ( $p>0.05)$.

Uric acid is a non-protein nitrogen constituent of blood. It is the end product of purine metabolism in man. Uric acid is excreted in the urine by the kidney. Estimation of uric acid is important in renal disorders and in diagnosis and management of gout. In this study, uric acid concentration varies slightly between the treated and control groups but the difference was not significant ( $p>0.05)$. This implied that administration of FF of $M$. myrictica had little or no effect on uric acid excretion hence, no deleterious effect on the organ that is responsible for uric acid excretion (Kidney).

The effects of repeated exposure (sub lethal) of FF of M. myristica on vital organs of rabbits (the brain, kidney, heart, lungs and liver) were investigated. No changes were observed in the morphology of the brain, kidney, heart, lungs and the liver of the control and the treated rabbits. This implied that sub chronic administration of FF of $M$. myristica had no effect on the morphology of these organs.

\section{Conclusion}

The toxicity studies of the FF of the spice Monodora myristica showed that the spice had little or no toxicity in all tested animals. Therefore, this spice can be considered relatively safe for oral consumption.

\section{REFERENCES}

Abdou BA, Njintang YN, Scher J, Mbofung CM. 2010. Phenolic compounds and radical scavenging potentials of twenty Cameroonian spices. Agric. Bio. J. North Am., 1(3): 213-224.
Aboaba OO, Ezeh AR, Anabuike CL. 2011. Antimicrobial activities of some Nigerian spices on some pathogens. Agric. Biol. J. North Am., 2(8): 1187-1193.

Adegoke E, Akinsanya A. 1970. Studies of Nigerian Medicinal Plants. J. West Afri. Sci. Assoc., 13(2): 15-65.

Aderogba MA, Mcgaw LJ, Ogundaini AO, Eloff JN. 2007. Antioxidant activity and cytotoxicity study of the flavonol glycosides from Bauhinia galpinii. Nat. Prod. Res., 21(7): 591-599.

Afolayan AJ, Yakubu MT. 2009. Effect of Bulbine natalensis Baker stem extract on the functional indices and histology of the liver and kidney of male Wister rats. $J$. Med. Food, 12: 814-820.

Agomuo EN, Onyenke EN, Anosike EO. 2011. Proximate Composition and Fatty acid profile of Monodora myristica (Ehuru) and Tetrapleura tetraptera (Uhiokirihio). Inter. Sci. Res. J., 3: 85 87.

Ajayi A, Adebowale KO, Dawodu FO, Oderinde RA. 2004. A study of the oil content of Nigerian grown Monodora myristica seeds for its nutritional and industrial applications. Pakistan J. Sci. Ind. Res., 47: $60-65$.

Akanji MA, Olagoke OA, Oloyede OB. 1993. Effects of chronic consumption of metabisuphite on the integrity of the kidney cellular system. Toxicol., 81: 173179.

Arts MJ, Haenen GR, Wilms LC, Beetstra SA, Heijnen CG, Vos HP, Bast A. 2002. Interactions between flavonoids and proteins effect on the total antioxidant capacity. J. Agric. Food Chem., 50: 11841187.

Brautbar N, Williams J. 2002. Industrial solvents and liver toxicity: risk assessment, risk factors and mechanisms. Int. J. Hyg. Environ. Health, 205: 479491.

Burkill HM. 1985. The Useful Plants of West Tropical Africa (vol. 1). Royal Botanic Gardens, Kew; 119-960. 
Burubai W. 2007. Modelling the load deformation Behavior of African nutmeg during cracking Ph.D thesis Department of Agricultural Engineering River State University, Portharcourt.

Chawla R. 1999. Biochemical tests for total proteins, albumin and pyruvate. In Practical Clinical Biochemistry Methods and Interpretations ( $2^{\text {nd }}$ edn). JAYPEE; 107-134.

Davis ME, Bredt ND. 1994. Renal methods for toxicity. In Principles and Methods of Toxicology (3rd edn), Hayes AWC (ed) Raven Press: New York; 871.

Ekeanyanwu RC, Etienajirhevwe OF. 2012. Invitro antihelmintic potentials of Xylopia aethiopica and Monodora myristica from Nigeria. African Journal of Biochemistry Research, 6(9): 115-120.

Ekeanyanwu RC, Ugu IG, Nwachuku UP. 2010. Biochemical characteristics of the African nutmeg, Monodora myristica. Agric. J., 5(5): 303-308.

Enwere NJ. 1988. Food of Plant Origin. Afro-orbis publications, Nsukka; 20-30.

Faleyimu OI, Oluwalana SA. 2008. Proximate Analysis of Monodora myristica (Gaertn) Dunal

(African Nutmeg) in Ogun State, Nigeria. World J. Biol. Res., 1(2): 22-30.

Gopinath A, Thakur AS, Khileswa S, Teeku S, Lincy J. 2010. Significance of Gamma Glutamyl transferase estimation in hepatobiliary Diseases. Inter. J. Applied Bio. Pharm. Tech., 1: 50-60.

Igwe CC, Yayi E, Moudachirou M. 2005. Chemical constituents of the solvent extracted and hydrodistilled Essential oil of African Nutmeg (Monodora myristica) and Turmeric ( Curcums domestia) from South West Nigeria. Nig. Food J., 23: $159-163$.

Iwu MM. 2002. Evaluation of the antihepatotoxic activity of the biflavonoids of Garciana kola seeds. J. Ethnopham., 21: 14-19.

James TM, Eagles PFK. 2010. Acute and subchronic oral toxicity profiles of the aqueous extract of Polygala fruticosa in female mice and rats. J. Ethnopharm., 128: $236-240$.
Jendrassick LG. 1938. Vereinfachte Photometrische Methoden Zur Bestimmung des Blutbilirubins. Biochem. Zeitschrift., 297: 82-87.

Kaplan A. 1995. Clinical Chemistry: Interpretation and Techniques ( $\left.{ }^{\text {th }} \mathrm{edn}\right)$. Williams and Wilkins: Baltimore; 514.

Keay RWJ. 1989. Trees of Nigeria (vol II). Claridon Press: Oxford; 5.

Latha RM, Geentha T, Varalashmi P. 1998. Effect of Vernonia cinerea Less. Flower extract in adjuvant-induced arthritis. Gen. Pharmacol., 31: 601-606.

Lorke D. 1983. A new approach to pratical acute toxicity testing. Archives of Toxicology, 54: 275-287.

McCue P, Shetty K. 2004. Inhibitory effects of rosmarinic acid extracts on porcine pancreatic amylase in vitro. Asia Pacific J. Clin. Nutr., 13(1): 101-106.

Mommensen TP, Walsh PJ. 1992. Biochemical and metal perspectives on nitrogen in fish. Experimentia, 48: 583593.

Nesaretnam K, Muhammad B. 1993. Nutritional properties of palm oil. Selected Readings on the Palm Oil and its Uses, 57-67.

Oben J, Ngondi JL, Kuate D, Etoundi CB. 2010. Antiamylase, antilipase and antioxidant effects of aqueous extracts of some Cameroonian Spices. J. Nat. Prod., 3: $165-171$.

Oboh G, Ekperigin MM. 2004. Nutritional evaluation of some Nigerian wild seeds. Nahrung Food, 48: 85-87.

OECD 401. 1981. Acute oral toxicity. Paris: Organisation for Economic Cooperation and Development. http://masetto. sourceoecd.org $/ \mathrm{vl}=80569188 / \mathrm{cl}=12 / \mathrm{nw}=1 / \mathrm{rps}$ v/ij/oecdjournals/1607310x/v1n4/s2/p1

Ogu GI, Ekeanyanwu RC, Madagwu EC, Eboh OJ, Okoye U. 2011. In vitro antimicrobial evaluation of African Nut meg (Monodora myristica) seeds. Inter. J. Trop. Agric. Sys., 15(1): 55-60.

Okafor JC. 1987. Development of Forest tree crops for food supply in Nigeria. Forest Eco. Manag., 1: 235-247.

Okeke EC. 1998. The use and chemical content of some indigenous Nigeria 
spices. J. Herbs Spices and Medicinal Plants, 5(4): 51-63.

Omobuwajo TO, Omobuwajo OR, Sanni LA. 2003. Physical properties of calabash nutmeg (Monodora myristica) seeds. J. Food Engin., 57: 375-381.

Owolabi MS, Oladimeji MO, Labunmi L, Singh G, Marimuthu P, Valey AI. 2008. Chemical Analysis and antibacterial effects of Cymbopogon citrates (dc) stapf volatile Oil from South-West Nigeria. $J$. Essen. Oil Plant Bearing, 2: 335-341.

Oyedapo OO, Akinpelu BA, Orefuwa SO. 2004. Antiinflammatory effects of Theobroma cacao, L. root extract. J. Trop. Med. Plants (Malaysia), 5(2): 161166.

Oyedapo OO. 1996. Studies on the biological activities of Plumbago zeylanica. Inter. J. Pharmacognosy, 34(5): 365-369.

Oyedemi SO, Yakubu MT, Afolayan AJ. 2010. Effect of aqueous extract of Leonotis leonorus (L.) leaves in male Wistar rats. Hum. Exp. Toxicol., 29: 377384.

Pearson DA. 1981. Chemical Analysis of Foods $\left(8^{\text {th }}\right.$ edn). Churchill Living Store, Edinburgh: London; 313-316.
Pruthi YS, Ramu SD, Jayaramen A. 1962. Studies on the chemical composition and sortion isotherms of spices. Spice Rok, Nat'lecon, p. 10.

Reitman S, Frankel S. 1957. A colometric method for the determination of Serum glutamic oxaloacetate and glutamic pyruvic transaminases. American J. Clin. Pathology., 35: 58-65.

Sanni MS, Van Ethen RL. 1978. An essential carboxylic acid group in human prostrate and phosphatase: Biochemica et Biophysica. Acta, 586: 307 - 376.

Schacterk GL, Pollack RL. 1973. A simplified method for the quantitative assay of small amount of protein in biological material. Anal. Biochem., 51: 654-660.

Udeala OK. 2000. Preliminary evaluation of dike fat a new tablet lubricant. J. Pharm. Pharmacol., 32: 6-9.

Uhegbu FO, Iweala EJ, Kanu I. 2011. Studies on the chemical and anti nutritional content of some Nigerian Spices. Inter. J. Nutri. Metab., 3(6): 72-76.

Umoh IB. 1988. Commonly used fruits in Nigeria. In Nutritional quality of plant food Post Harvest Research Unit, Osagie, Eka (eds). University of Benin. 